\title{
Clustering Assay for Studying the Interaction of Membrane Proteins With PDZ Domain Proteins
}

\author{
Jaewon Ko and Eunjoon Kim
}

\begin{abstract}
Summary
Some membrane proteins must be clustered at target sites to efficiently perform their functions. PDZ domain-containing scaffold proteins bind to the tails of target membrane proteins and promote their localization and clustering on the cell surface. This chapter describes the experimental details of the clustering assay, using the interaction between potassium channels and PSD-95, an abundant PDZ domain protein in neuronal synapses, as a model.
\end{abstract}

Key Words: Membrane protein; clustering; PSD-95; PDZ; immunocytochemistry.

\section{Introduction}

For proper function, membrane proteins, including receptors, ion channels, and cell adhesion molecules, must cluster on the membrane surface at their specific target sites. The clustering of membrane proteins is thought to be mediated by interaction of their cytoplasmic regions with scaffolding proteins.

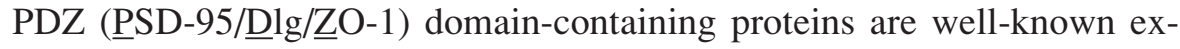
amples of such scaffolding proteins. The PDZ domain is an approx 90-aminoacid module that mediates protein-protein interaction and is found in more than 400 proteins in the human and mouse (1-6). It is a globular domain that contains a groove and hydrophobic pockets on its surface, through which it binds the C-terminus of its target proteins (7).

One of the best-characterized PDZ domain-containing proteins is PSD-95, a key scaffolding protein at neuronal synapses (1-6). The three PDZ domains of PSD-95 bind the C-termini of various membrane proteins, including potassium channels and $N$-methyl-D-aspartate receptors $(\mathbf{8}-10)$. In addition to membrane proteins, PSD-95 interacts with a variety of signaling, scaffolding, and

From: Methods in Molecular Biology, vol. 332: Transmembrane Signaling Protocols, Second Edition Edited by: H. Ali and B. Haribabu (c) Humana Press Inc., Totowa, NJ 
cytoskeletal proteins (11-14), contributing to the assembly of macromolecular protein complexes in excitatory neuronal synapses.

The clustering assay is an in vitro experimental system that can be used to analyze the interaction between membrane proteins and PDZ domain proteins. In the clustering assay, co-expressed membrane and PDZ domain proteins form clusters at the surface membrane, where they are co-localized. In contrast, when expressed alone, membrane and PDZ proteins do not form clusters and are usually diffusely distributed throughout the cell.

PSD-95 was first shown to cluster Kv1.4 potassium channels on the plasma membrane of heterologous cells (8). Subsequently, PSD-95 has been shown to cluster a variety of other membrane proteins, including inward rectifier potassium channels, glutamate receptor subunits, $\alpha 1$-adrenergic receptors, stargazin ( $\alpha$-amino-3-hydroxy-5-methyl-4-isoxazolepropionic acid glutamate receptorinteracting membrane protein), and frizzled (receptor for Wnt proteins $[8,15-$ 22]). PICK1, another PDZ protein, has been shown to cluster membrane proteins, including ephrins and their receptors, GluR2, mGluR7 glutamate receptor subunits, UNC5H (receptor for netrin-1), and the monoamine plasma membrane transporter (23-27). Other PDZ proteins shown to cluster membrane proteins include GRIP, Shank/ProSAP, and S-SCAM (28-30). Thus, the interaction of membrane proteins with PDZ proteins appears to be a mechanism by which membrane proteins are clustered at their target membranes.

Although clustering of membrane proteins is an interesting phenomenon, its underlying mechanism and physiological significance are still largely elusive. In the case of the well-known clustering of potassium channels by PSD-95, important molecular mechanisms underlying the clustering include the direct interaction between the potassium channel and PSD-95, the multimeric nature of both potassium channels and PSD-95, the palmitoylation of PSD-95, and the intramolecular interaction between the Src homology $(\mathrm{SH}) 3$ and guanylate kinase domains of PSD-95 (31-36). A current model for the clustering of potassium channels by PSD-95 is that the clusters represent two-dimensional lattice-like structures in which multimeric channels and PSD-95 form a macromolecular complex. Unlike PSD-95, SAP97, a member of the PSD-95 family, has been shown to cause the formation of intracellular clusters of potassium channels in heterologous cells $(35,37)$, suggesting that clustering might have functions at sites other than the plasma membrane.

Although further studies must be performed to understand the mechanisms and roles of the clustering phenomenon, the clustering assay, together with other in vitro methods, can be used to help investigate the interaction of membrane proteins with their cytosolic scaffolds. In this chapter, we describe experimental details of the clustering assay using the interaction between the Kv1.4 potassium channel and PSD-95 in heterologous cells as a model. 


\section{Materials}

\subsection{Cell Culture and Transfection}

1. COS-7 cells or other heterologous cells (American Type Culture Collection, Rockville, MD; see Note 1).

2. Dulbecco's modified Eagle's medium (DMEM; Invitrogen, Life Technologies, Rockville, MD).

3. Heat-inactivated fetal bovine serum (Invitrogen, Life Technologies).

4. Gentamicin (Invitrogen, Life Technologies).

5. LipofectAMINE (Invitrogen, Life Technologies).

6. Opti-MEM I reduced serum medium (Invitrogen, Life Technologies).

7. Sterile round microscope glass cover slips (13 or $18 \mathrm{~mm}$ diameter; Fisher Scientific, Pittsburgh, PA).

8. 12-Well tissue culture plates (Nunc, Kamstrupvej, Danmark).

9. Microscope slides $(25 \times 75 \times 1 \mathrm{~mm}$; Fisher Scientific, Pittburgh, PA).

10. Poly-D-lysine (Sigma, St. Louis, MO).

11. Porcelain rack (Thomas Scientific, Swedesboro, NJ).

12. Glass chamber for nitric acid washing.

13. Nitric acid (Junsei Company, Japan).

\subsection{Immunocytochemistry}

1. Phosphate-buffered saline (PBS): $135 \mathrm{~m} M \mathrm{NaCl}, 4.5 \mathrm{~m} M \mathrm{Na}_{2} \mathrm{HPO}_{4}, 1.5 \mathrm{~m} M$ $\mathrm{KH}_{2} \mathrm{PO}_{4}, \mathrm{pH}$ 7.4.

2. Paraformaldehyde (Sigma).

3. $100 \%$ Cold $\left(-20^{\circ} \mathrm{C}\right)$ methanol (Merck, Darmstadt, Germany; absolute grade).

4. Triton X-100 (Amresco, Santa Cruz, CA).

5. Blocking buffer: $3 \%$ horse serum, $0.1 \%$ crystalline-grade bovine serum albumin in PBS.

6. Store at $4{ }^{\circ} \mathrm{C}$ or $-20^{\circ} \mathrm{C}$ (for long-term storage).

7. Vectashield mounting solution (Vector Laboratories, Burlingame, CA).

8. Primary antibodies against the proteins expressed in heterologous cells. Store in aliquots at $4^{\circ} \mathrm{C}$ or $-70^{\circ} \mathrm{C}$ (for long-term storage).

10. Secondary antibodies conjugated to fluorescent dyes, such as $\mathrm{Cy} 3$ (red) or fluorescein isothiocyanate (FITC) (green; Jackson Research Laboratory, West Grove, PA).

\subsection{Fluorescence Microscopy}

Confocal laser scanning or conventional fluorescence microscope with appropriate detection filters and water or oil objectives with high numerical apertures $(\times 40$ or $\times 63$ for most applications).

\section{Methods}

\subsection{Cleaning Cover Slips}

1. Place round cover slips in a porcelain rack and, in a hood, submerge the rack for 36 to $48 \mathrm{~h}$ in a glass chamber containing nitric acid. 
2. Rinse the cover slips with MilliQ water twice for $1 \mathrm{~h}$ and twice more for $30 \mathrm{~min}$.

3. Cover the rack containing the washed cover slips with aluminum foil.

4. Bake the rack in a furnace for $6 \mathrm{~h}$ at $225^{\circ} \mathrm{C}$.

\subsection{Coating Cover Slips}

1. Place round cover slips in 12-well plates (one cover slip in each well).

2. Place and spread approx $100 \mu \mathrm{L}$ (or enough to cover the surface) of poly-D-lysine $\left(1 \mu \mathrm{g} / \mathrm{mL}\right.$ in $\left.\mathrm{H}_{2} \mathrm{O}\right)$ on the surface of each cover slip.

3. Close the lid of the 12-well plate and incubate the plate overnight at room temperature.

4. Rinse the cover slips three times with sterile water.

\subsection{Transfecting Cells}

1. Spread cells onto coated cover slips in a 12-well plate at low density (15 to $20 \%$ confluence).

2. Incubate the plate overnight in a $5 \% \mathrm{CO}_{2}$ incubator at $37^{\circ} \mathrm{C}$. This step will allow the attachment of the cells to the surface of coated cover slips.

3. Transfect the cells with mammalian expression plasmids using LipofectAMINE according to the manufacturer's protocols (see Note 2). Briefly mix $2.4 \mu \mathrm{L}$ of LipofectAMINE with $40 \mu \mathrm{L}$ of Opti-MEM. Meanwhile, incubate $0.4 \mu \mathrm{g}$ of expression constructs (for co-transfections, $0.2 \mu \mathrm{g}$ each) in $40 \mu \mathrm{L}$ of Opti-MEM. Mix the DNA with LipofectAMINE, and incubate for $30 \mathrm{~min}$ at room temperature.

4. Add $320 \mu \mathrm{L}$ of Opti-MEM to the DNA + lipid mixture (total volume $400 \mu \mathrm{L}$ ).

5. Wash the cells once with Opti-MEM.

6. Place all of the of the final mixture $(400 \mu \mathrm{L})$ onto each well and incubate the plate for 4 to $6 \mathrm{~h}$ in a $5 \% \mathrm{CO}_{2}$ incubator at $37^{\circ} \mathrm{C}$.

7. After the incubation, replace Opti-MEM with $1 \mathrm{~mL}$ of prewarmed $\left(37^{\circ} \mathrm{C}\right) \mathrm{DMEM}$ supplemented with $5 \%$ fetal bovine serum.

8. After $24 \mathrm{~h}$ of incubation in a $5 \% \mathrm{CO}_{2}$ incubator at $37^{\circ} \mathrm{C}$, examine the cells with a microscope. If cell debris is observed, exchange the old media with fresh, prewarmed $\left(37^{\circ} \mathrm{C}\right)$ DMEM.

\subsection{Immunocytochemistry}

1. Forty-eight hours after transfection, wash the cover slips three times for $5 \mathrm{~min}$ each with PBS (with gentle shaking). This step and the following steps in this section can be performed in new 12 -well plates.

2. Fix the cells for 5 min with $4 \%$ paraformaldehyde in PBS (see Note 3 ) or with cold methanol $\left(-20^{\circ} \mathrm{C}\right.$; see Note 4$)$.

3. Wash the cells three times for 5 min each with PBS.

4. Permeabilize the cells for 2 min with $0.1 \%$ Triton X-100 in PBS.

5. Wash the cells three times for 5 min each with PBS.

6. Incubate the cells for $30 \mathrm{~min}$ with blocking buffer at room temperature with gentle shaking. 
7. Incubate the cells for $1 \mathrm{~h}$ at room temperature with relevant primary antibodies in blocking buffer. The primary antibody concentration and incubation time can be adjusted if necessary (see Note 5).

8. Wash the cells three times for 10 min each with PBS.

9. Incubate the cells for $30 \mathrm{~min}$ at room temperature with fluorescence dyeconjugated secondary antibodies (Cy3, Cy5, or FITC) in blocking buffer. The incubation time can be extended to $1 \mathrm{~h}$ if necessary.

10. Wash the cells three times for 10 min each with PBS.

11. Place approx $50 \mu \mathrm{L}$ of Vectashield solution on a microscope slide, and carefully place the stained cover slip face (cell-attached side down) onto the wetted area of the slide. Try to avoid forming bubbles.

\subsection{Image Acquisition and Data Analysis}

Fluorescence images are acquired using a confocal or conventional fluorescence microscope usually using $\times 40$ or $\times 63$ water or oil objectives. Acquire the images of co-transfected cells using both channels (e.g., Cy3 and FITC channels; Fig. 1; see Note 6). Co-clustering efficiency is quantified by measuring the number of cells showing co-clusters out of the total number of co-transfected cells.

\section{Notes}

1. COS-7 cells are flatter than other heterologous cells, such as HEK293T-cells. Because co-clusters are more easily observed in flatter cells than in other less flat cells, COS-7 cells are preferred for the co-clustering assay.

2. In our experience, high expression levels of transfected proteins are important for successful co-clustering experiments. Thus, we recommend the use of mammalian expression vectors with strong promoters, such as cytomegalovirus. Single transfections are useful negative controls for the clustering assay. In addition, mutant proteins that cannot interact with PDZ domain proteins, including point mutants in the C-terminus or deletion mutants lacking the last three or four amino acid residues, can also be used as negative controls.

3. High-quality paraformaldehydes are recommended for immunocytochemistry experiments.

4. Methanol often is preferred for the fixation of cytoskeletal proteins. When methanol is used as a fixative, permeabilization can be omitted because methanol also permeabilizes the cells. The use of high-quality methanol is recommended.

5. The standard concentration for primary antibodies is $1 \mu \mathrm{g} / \mathrm{mL}$. If low expression levels of the transfected proteins are expected, use a higher concentration of primary antibodies and an extended incubation time (as long as $2 \mathrm{~h}$ ).

6. The presence of co-clusters on the surface of cells can be supported by Z-stack optical sectioning of the cells in confocal laser scanning microscopy (Fig. 1). 

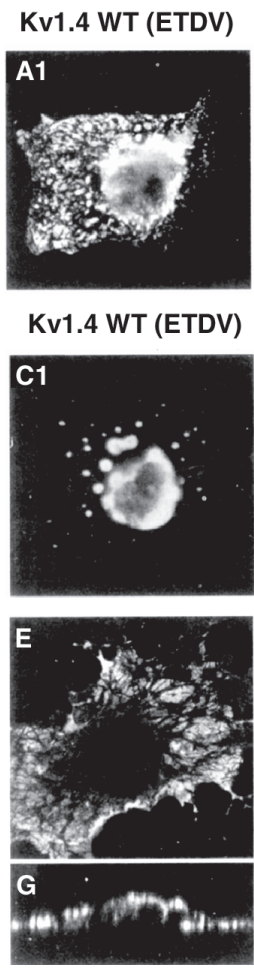

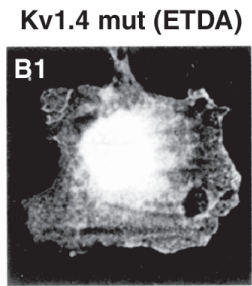

Kv1.4 mut (ETDA)

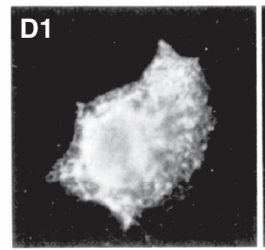

PSD-95

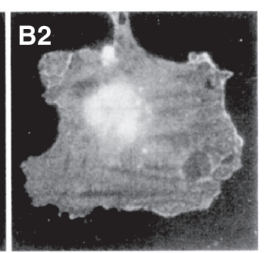

SAP97

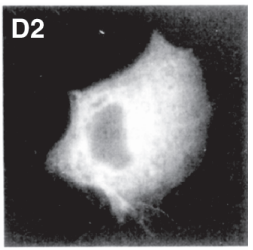

Fig. 1. Different patterns of Kv1.4 co-clustering with PSD-95 and SAP97. COS-7 cells were co-transfected as follows: (A,E,G) wild-type Kv1.4 and PSD-95; (B) Kv1.4 C-terminal -ETDA mutant and PSD-95; (C,F,H) wild-type Kv1.4 and SAP97; (D) Kv1.4 C (-ETDA) mutant and SAP97. Each pair of pictures (A1,A2-D1,D2) represents the same co-transfected cell visualized through different immunofluorescence filter channels. As indicated, the left half of each pair (A1,B1,C1,D1) shows the distribution of the Kv1.4 or Kv1.4 mutant, visualized with Cy3-labeled secondary antibodies; the right half (A2,B2,C2,D2) shows the distribution of PSD-95 or SAP97, labeled with fluorescein isothiocyanatesecondary antibodies. Only the wild-type Kv1.4 shows co-clustering with PSD-95 and SAP97. In cells co-transfected with Kv1.4 (-ETDA) mutant and PSD-95 or SAP97, both proteins are diffusely distributed in a pattern similar to singly transfected cells. (E-H) Confocal microscope images show that PSD-95/ Kv1.4 co-clusters are on, or very close to, the surface, whereas SAP97 forms coaggregates with Kv1.4 that are intracellular and concentrated in the perinuclear region. (E) and (F) are horizontal confocal sections and $(\mathbf{G})$ and $(\mathbf{H})$ are vertical sections (only Kv1.4 immunofluorescence is shown). Arrowhead in $\mathrm{H}$ indicates an intracellular aggregate of Kv1.4 in a cell co-transfected with SAP97. In (G), two layers of Kv1.4 clusters can be discerned toward the thicker middle part of the cell, presumably associated with adherent and nonadherent surfaces of the cell. This figure was reprinted from Fig. 1 of ref. 37. 


\section{References}

1. Kim, E. and Sheng, M. (2004) PDZ domain proteins of synapses. Nat. Rev. Neurosci. 10, 771-781.

2. Sheng, M. and Sala, C. (2001) PDZ domains and the organization of supramolecular complexes. Annu. Rev. Neurosci. 24, 1-29.

3. McGee, A. W. and Bredt, D. S. (2003) Assembly and plasticity of the glutamatergic postsynaptic specialization. Curr. Opin. Neurobiol. 13, 111-118.

4. Montgomery, J. M., Zamorano, P. L., and Garner, C. C. (2004) MAGUKs in synapse assembly and function: an emerging view. Cell Mol. Life Sci. 61, 911-929.

5. Garner, C. C., Nash, J., and Huganir, R. L. (2000) PDZ domains in synapse assembly and signalling. Trends Cell Biol. 10, 274-280.

6. Kennedy, M. B. (2000) Signal-processing machines at the postsynaptic density. Science 290, 750-754.

7. Doyle, D. A., Lee, A., Lewis, J., Kim, E., Sheng, M., and MacKinnon, R. (1996) Crystal structures of a complexed and peptide-free membrane protein- binding domain: molecular basis of peptide recognition by PDZ. Cell 85, 1067-1076.

8. Kim, E., Niethammer, M., Rothschild, A., Jan, Y. N., and Sheng, M. (1995) Clustering of Shaker-type $\mathrm{K}+$ channels by interaction with a family of membraneassociated guanylate kinases. Nature 378, 85-88.

9. Kornau, H. C., Schenker, L. T., Kennedy, M. B., and Seeburg, P. H. (1995) Domain interaction between NMDA receptor subunits and the postsynaptic density protein PSD-95. Science 269, 1737-1740.

10. Niethammer, M., Kim, E., and Sheng, M. (1996) Interaction between the C terminus of NMDA receptor subunits and multiple members of the PSD-95 family of membrane-associated guanylate kinases. J. Neurosci. 16, 2157-2163.

11. Brenman, J. E., Chao, D. S., Gee, S. H., et al. (1996) Interaction of nitric oxide synthase with the postsynaptic density protein PSD-95 and alpha1-syntrophin mediated by PDZ domains. Cell 84, 757-767.

12. Chen, H. J., Rojas-Soto, M., Oguni, A., and Kennedy, M. B. (1998) A synaptic Ras-GTPase activating protein (p135 SynGAP) inhibited by CaM kinase II. Neuron 20, 895-904.

13. Kim, J. H., Liao, D., Lau, L. F., and Huganir, R. L. (1998) SynGAP: a synaptic RasGAP that associates with the PSD-95/SAP90 protein family. Neuron 20, 683-691.

14. Kim, E., Naisbitt, S., Hsueh, Y. P., et al. (1997) GKAP, a novel synaptic protein that interacts with the guanylate kinase- like domain of the PSD-95/SAP90 family of channel clustering molecules. J. Cell Biol. 136, 669-678.

15. Garcia, E. P., Mehta, S., Blair, L. A., et al. (1998) SAP90 binds and clusters kainate receptors causing incomplete desensitization. Neuron 21, 727-739.

16. Roche, K. W., Ly, C. D., Petralia, R. S., et al. (1999) Postsynaptic Density-93 Interacts with the delta2 Glutamate Receptor Subunit at Parallel Fiber Synapses. J. Neurosci. 19, 3926-3934. 
17. Hu, L. A., Tang, Y., Miller, W. E., et al. (2000) Beta 1-adrenergic receptor association with PSD-95. Inhibition of receptor internalization and facilitation of beta 1-adrenergic receptor interaction with N-methyl-D-aspartate receptors. J. Biol. Chem. 275, 38,659-38,666.

18. Wong, W., Newell, E. W., Jugloff, D. G., Jones, O. T., and Schlichter, L. C. (2002) Cell surface targeting and clustering interactions between heterologously expressed PSD-95 and the Shal voltage-gated potassium channel, Kv4.2. J. Biol. Chem. 277, 20,423-20,430.

19. Nehring, R. B., Wischmeyer, E., Doring, F., Veh, R. W., Sheng, M., and Karschin, A. (2000) Neuronal inwardly rectifying $\mathrm{K}(+)$ channels differentially couple to PDZ proteins of the PSD-95/SAP90 family. J. Neurosci. 20, 156-162.

20. Chen, L., Chetkovich, D. M., Petralia, R. S., et al. (2000) Stargazin regulates synaptic targeting of AMPA receptors by two distinct mechanisms. Nature 408, 936-943.

21. Hering, H. and Sheng, M. (2002) Direct interaction of Frizzled-1, -2, -4, and -7 with PDZ domains of PSD-95. FEBS Lett. 521, 185-189.

22. Kim, E., Cho, K. O., Rothschild, A., and Sheng, M. (1996) Heteromultimerization and NMDA receptor-clustering activity of Chapsyn-110, a member of the PSD95 family of proteins. Neuron 17, 103-113.

23. Xia, J., Zhang, X., Staudinger, J., and Huganir, R. L. (1999) Clustering of AMPA receptors by the synaptic PDZ domain-containing protein PICK1. Neuron 22, 179-187.

24. Williams, M. E., Wu, S. C., McKenna, W. L., and Hinck, L. (2003) Surface expression of the netrin receptor $\mathrm{UNC5H} 1$ is regulated through a protein kinase C-interacting protein/protein kinase-dependent mechanism. J. Neurosci. 23, 11,279-11,288.

25. Boudin, H., Doan, A., Xia, J., et al. (2000) Presynaptic clustering of mGluR7a requires the PICK1 PDZ domain binding site. Neuron 28, 485-497.

26. Torres, G. E., Yao, W. D., Mohn, A. R., et al. (2001) Functional interaction between monoamine plasma membrane transporters and the synaptic PDZ domaincontaining protein PICK1. Neuron 30, 121-134.

27. Torres, R., Firestein, B. L., Dong, H., et al (1998) PDZ proteins bind, cluster, and synaptically colocalize with Eph receptors and their ephrin ligands. Neuron 21, 1453-1463.

28. Hirao, K., Hata, Y., Yao, I., et al. (2000) Three isoforms of synaptic scaffolding molecule and their characterization. Multimerization between the isoforms and their interaction with N-methyl-D-aspartate receptors and SAP90/PSD-95associated protein. J. Biol. Chem. 275, 2966-2972.

29. Tobaben, S., Sudhof, T. C., and Stahl, B. (2000) The G protein-coupled receptor CL1 interacts directly with proteins of the Shank family. J. Biol. Chem. 275, 36,204-36,210.

30. Bruckner, K., Pablo Labrador, J., Scheiffele, P., Herb, A., Seeburg, P. H., and Klein, R. (1999) EphrinB ligands recruit GRIP family PDZ adaptor proteins into raft membrane microdomains. Neuron 22, 511-524. 
31. Hsueh, Y. P., Kim, E., and Sheng, M. (1997) Disulfide-linked head-to-head multimerization in the mechanism of ion channel clustering by PSD-95. Neuron 18, 803-814.

32. El-Husseini, A. E., Topinka, J. R., Lehrer-Graiwer, J. E., et al. (2000) Ion channel clustering by membrane-associated guanylate kinases. Differential regulation by N-terminal lipid and metal binding motifs. J. Biol. Chem. 275, 23,904-23,910.

33. Christopherson, K. S., Sweeney, N. T., Craven, S. E., Kang, R., El-Husseini Ael, D., and Bredt, D. S. (2003) Lipid- and protein-mediated multimerization of PSD95: implications for receptor clustering and assembly of synaptic protein networks. J. Cell Sci. 116, 3213-3219.

34. Shin, H., Hsueh, Y. P., Yang, F. C., Kim, E., and Sheng, M. (2000) An intramolecular interaction between Src homology 3 domain and guanylate kinase-like domain required for channel clustering by postsynaptic density-95/SAP90. $J$. Neurosci. 20, 3580-3587.

35. Tiffany, A. M., Manganas, L. N., Kim, E., Hsueh, Y. P., Sheng, M., and Trimmer, J. S. (2000) PSD-95 and SAP97 exhibit distinct mechanisms for regulating $\mathrm{K}(+)$ channel surface expression and clustering. J. Cell Biol. 148, 147-158.

36. Hsueh, Y. P. and Sheng, M. (1999) Requirement of N-terminal cysteines of PSD95 for PSD-95 multimerization and ternary complex formation, but not for binding to potassium channel Kv1.4. J. Biol. Chem. 274, 532-536.

37. Kim, E. and Sheng, M. (1996) Differential $\mathrm{K}^{+}$channel clustering activity of PSD95 and SAP97, two related membrane-associated putative guanylate kinases. Neuropharmacology 35, 993-1000. 
